\title{
Stakeholders of Voluntary Forest Carbon Offset Projects in China: An Empirical Analysis
}

\author{
Derong Lin ${ }^{1}$ and Yingzhi Lin ${ }^{2}$ \\ ${ }^{1}$ School of Economics and Management, Qingdao Agricultural University, Qingdao 266109, China \\ ${ }^{2}$ School of Mathematics and Physics, China University of Geosciences, No. 388 Rumo Road, Wuhan 430074, China \\ Correspondence should be addressed to Yingzhi Lin; linyz.ccap@igsnrr.ac.cn
}

Received 18 July 2014; Accepted 20 September 2014

Academic Editor: Qun'ou Jiang

Copyright (c) 2015 D. Lin and Y. Lin. This is an open access article distributed under the Creative Commons Attribution License, which permits unrestricted use, distribution, and reproduction in any medium, provided the original work is properly cited.

\begin{abstract}
Climate change is one of the defining challenges facing the planet. Voluntary forest carbon offset project which has the potential to boost forest carbon storage and mitigate global warming has aroused the global concern. The objective of this paper is to model the game situation and analyze the game behaviors of stakeholders of voluntary forest carbon offset projects in China. A stakeholder model and a Power-Benefit Matrix are constructed to analyze the roles, behaviors, and conflicts of stakeholders including farmers, planting entities, communities, government, and China Green Carbon Foundation. The empirical analysis results show that although the stakeholders have diverse interests and different goals, a win-win solution is still possible through their joint participation and compromise in the voluntary forest carbon offset project. A wide governance structure laying emphasis on benefit balance, equality, and information exchanges and being regulated by all stakeholders has been constructed. It facilitates the agreement among the stakeholders with conflicting or different interests. The joint participation of stakeholders in voluntary forest carbon offset projects might change the government-dominated afforestation/reforestation into a market, where all participators including government are encouraged to cooperate with each other to improve the condition of fund shortage and low efficiency.
\end{abstract}

\section{Introduction}

According to the Intergovernmental Panel on Climate Change (IPCC) and World Meteorological Organization, the global climate is changing as the direct result of greenhouse gas (GHG) emissions from human activities including burning fossil fuels for energy, land clearing, and agriculture $[1,2]$. While GHG emission reduction is called upon worldwide, a large body of evidence indicates that GHG emissions will continue increasing rapidly. It seems to be impossible to achieve the goal of the Copenhagen Accord of limiting the global temperature increase to $2^{\circ} \mathrm{C}$ [3]. Land use, land-use change, and forestry is regarded as one of the adequate and cost-effective measures that remove carbon dioxide from the atmosphere, therefore mitigating global warming [4-6]. The Fourth Assessment Report of IPCC indicates that afforestation will be an economical and feasible measure of mitigation and adaption climate change in the next 30 to 50 years. It is believed that the climate change mitigation goal will be hardly achieved if global deforestation cannot be reduced and afforestation cannot be accelerated in Post-Kyoto Times [7]. With the largest area of artificial forest (about 62 million hectares), China is still working on afforestation $[8,9]$. Its experiences and challenges are of global significance.

Afforestation and sustainable forest management have been embodied in global strategies of climate change mitigation and adaption and proceeded to practice. A series of significant international climate change agreements have been established by United Nations Framework Convention on Climate Change, providing commercialization and marketization opportunities for forest carbon credits. The voluntary compensation of GHG emissions has become a new business domain which is increasingly arousing public interest [10]. Forest carbon market has become the most dynamic market for forest environmental services and might be the forestry market with the highest growth potential in 
the future. It has become a new trend to develop forest carbon market to vitalize forest carbon offsets and forestry economy via forest carbon projects [11-13].

The decisions and behaviors of participants of forest carbon market are important factors that influence forest carbon transactions. The research of Cao et al. based on expert interview and structured questionnaire survey indicated that credit quality, common benefit, willingness to pay, and carbon-sink price/cost were the main determinants of forest carbon market in Asia [14]. Markowski-Lindsay et al. estimated the probability forest owners in Massachusetts would participate in carbon market and found that very few forest owners expressed interest in participating under a carbon scenario similar to the current voluntary scheme. They concluded that early withdrawal penalties, additionality requirements, and contract length are concerned by forest owners other than price, and harvesting plans, opinions about forest usage, and beliefs about climate change also play significant roles in the decision to participate [15]. Miller et al. assessed the forest owner interest in selling forest carbon credits in the Lake States, USA, and found that carbon credit payment amount, contract length, gender, value placed on other nonmarket forest amenities, need for additional income, attitude towards climate change, absentee status, land tenure, and total acres owned were all significant determinants [16].

The principal barriers and influencing factors of participation in the forest carbon market and projects have been discussed in previous researches, furnishing a lot of information for forest carbon market development [1721]. Meanwhile, it is still undiscovered how those factors integrally motivate or prevent stakeholders to participate in the forest carbon market $[22,23]$. The integrated effect of all the benefit-driving forces of different stakeholders is the focus of this paper. The major contribution of this paper is that it provides an analysis framework and some general conclusions of voluntary forest carbon offset projects. A comprehensive discussion on the roles, behaviors, and conflicts of stakeholders of voluntary forest carbon offset projects in China such as farmers, planting entities, communities, government, and China Green Carbon Foundation (CGCF) is carried out based on a stakeholder model and a PowerBenefit Matrix.

This paper is organized as follows. Section 2 briefly reviews the forest carbon offset projects and the status of forest carbon transactions in China and presents the proposed stakeholder model and Power-Benefit Matrix of CGCF voluntary forest carbon offset projects in China. Section 3 summarizes the role orientation and driving factors of key stakeholders and discusses their behaviors and conflicts, and Section 4 concludes the paper.

\section{Materials and Methods}

2.1. Forest Carbon Transaction in China. Attaching great importance to climate change, government of China made great efforts in forestry development. Forestry was regarded as one of the most important domains dealing with climate change by China's National Climate Change Program issued by the National Development and Reform Commission (NDRC) in 2007 [24]. The Outline of China's Forestry Action Plan to Address Climate Change released in 2009 intends to improve forest quality by forest management and protection. The concrete goal of forestry development announced by government of China is to expand its total forest area by 40 million hectares and increase the country's total forest inventory by 1.3 billion cubic meters by 2020 compared with those in 2005 [25].

Although its potential to be one of the most effective measures to address climate change by increasing forest carbon sink has been widely recognized, the development of forest carbon offset project is falling behind expectation. In China, the forest carbon offset projects are still in their infancy, which are fewer in quantity and smaller in scale compared with greenhouse gas emission reduction projects in industrial and energy sectors [26-28]. Concretely, there are two types of forest carbon offset projects in China, afforestation and reforestation (AR) projects under the clean development mechanism (CDM) and voluntary forest carbon offset projects $[29,30]$. Since the first CDM reforestation project worldwide registered in Pearl River Basin, five CDM AR projects have been registered in China with a total transaction volume of about 440 million ton carbon dioxide according to statistics from the United Nations.

Volunteer actions of all levels of government, commodities, and individuals to reduce GHG emissions are also advocated besides CDM AR projects. The CGCF funding tree plantation and forest carbon sequestration by selling voluntary carbon offsets to firms and individuals is founded in 2010. All the voluntary forest carbon offset projects are carried out through CGCF in China ever since. By 2012, according to the statistics of CGCF, the foundation had raised about 600 million China Yuan (CNY) and set up 15 special funds according to donor intention and orientation, owning about 80 thousand hectares of carbon sink forest which spread over more than 20 provinces/municipalities all over China. On the whole, most of the voluntary forest carbon offset projects are located in comparatively developed districts such as Zhejiang Province, Fujian Province, Beijing Municipality, and Guangdong Province. The relatively complete markets and higher income levels and fiscal revenue there are beneficial to voluntary forest carbon offsets [11]. The nonprofit feature of CGCF determines that all the funds from firms and individuals are donations rather than investments, which significantly limits the funding sources. Consequently, CGCF and a majority of its donors expect the carbon credits can be traded in carbon markets and generate economic benefits [31]. A pilot project of domestic forest carbon transaction is launched by CGCF and Huadong Forestry Exchange in November 2011. Immediately after its launch, 148 thousand carbon credits (equivalent corresponds to 148 thousand ton of carbon dioxide) are subscribed [32]. However, this subscription becomes the only domestic forest carbon transaction of the pilot project so far. 


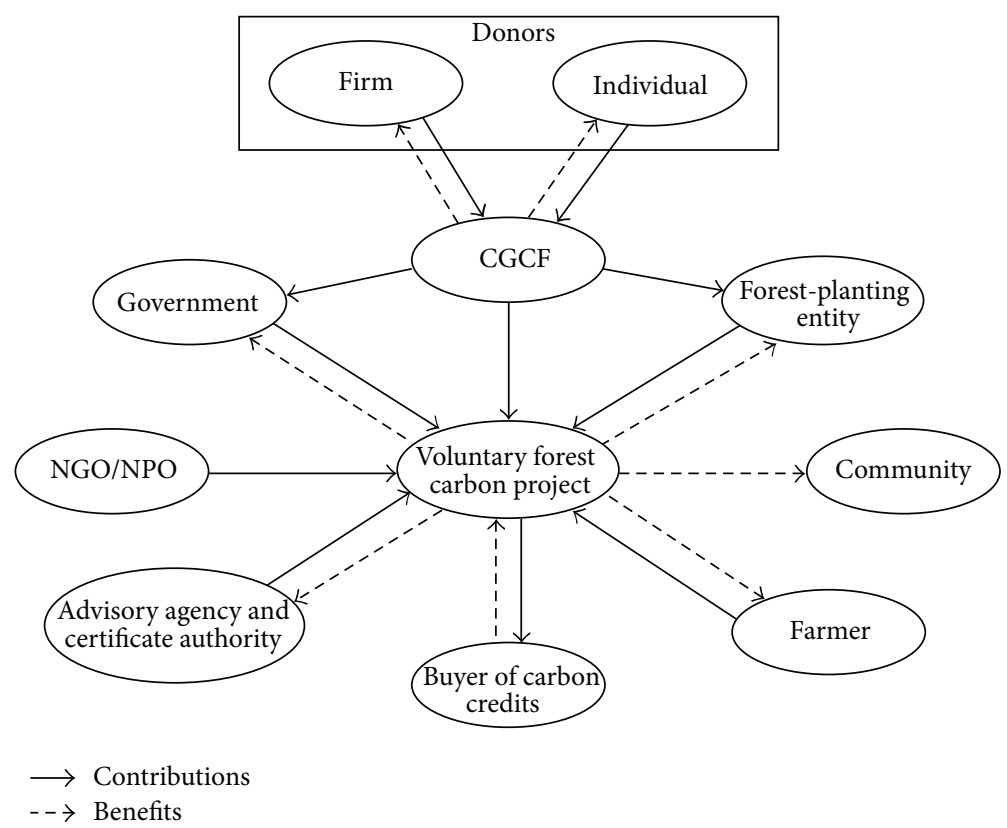

FIGURE 1: Stakeholder model of CGCF voluntary forest carbon offset projects in China.

2.2. Stakeholder Model. Stakeholder theory has been applied in many fields such as source management, business ethics, and even irregular warfare as a method of system analysis $[33,34]$. According to the theory, all the individuals and groups influencing or influenced by the achievement of organization goals are counted as stakeholders [35]. Stakeholder model succeeds in challenging the usual analysis approaches because it takes all the stakeholders' needs into consideration [36]. It is applied in this research to describe the relationship and interaction of stakeholders of voluntary forest carbon offset projects in China.

By considering the management pattern of CGCF voluntary forest carbon offset projects, CGCF, donor (firm and individual), forest-planting entity, buyer of carbon credits, land user (mainly farmers after forest tenure reform), government, community, nongovernmental organization/nonprofit organization (NGO/NPO), advisory agency, and certificate authority are counted as stakeholders (Figure 1). CGCF is the core of project management, obtaining donations from the firms and individuals, cooperating with local government to promote and organize the project, and employing forestplanting entities. The firms and individuals donate money for CGCF voluntary forest carbon offset projects, restrain the use of the funds, and own the carbon credits generated by the project. Forest-planting entities are employed by CGCF to carry out the projects (afforestation/reforestation and forest management). The local government is involved because it is the competent authority of land use change in China and can promote the project by policy support and subsidies. In general, farmers transfer their land use right to CGCF and own the property right of lumbers. The carbon credits generated in the project are measured, monitored, certified and registered by advisory agency and certificate authority, and recorded in the social responsibility accounts of their donors. The NGO/NPO may provide aids and information for CGCF voluntary forest carbon offset projects. The generated carbon credits can circulate on the market and sell to the buyers of carbon credits.

2.3. Power-Benefit Matrix. Power-Benefit Matrix can be used to plot and analyze stakeholders. It displays how stakeholders express their expectations and whether they have the power to make an impact. The effectiveness of CGCF voluntary forest carbon offset projects are directly determined by the behaviors of stakeholders. Meanwhile, stakeholders' behaviors root in their willingness which depends on their rights and obligations (more concretely powers and benefits) in CGCF voluntary forest carbon offset projects. Consequently, the rights and obligations are the key factors in analyzing stakeholders in CGCF voluntary forest carbon offset projects.

\section{Results and Discussion}

3.1. Role Orientation of Key Stakeholders. With the stakeholder model of CGCF voluntary forest carbon offset projects in China, the role orientation and driving factors of stakeholders are summarized (Table 1). The various role orientations of stakeholders determine the decision makings and behavior choices to have different influences on CGCF voluntary forest carbon offset projects in China. Farmers and forest-planting entities are key stakeholders in China because their low participation willingness, participation capacity, and participation degree are major limits for the CGCF voluntary forest carbon offset project implementation. The role orientations and behavior choices of these two types of stakeholders are discussed in depth in this section.

According to ownerships, the forest land can be divided into two types in China, state-owned forest land and 
TABLE 1: Role orientation and driving factors of stakeholders involved in CGCF voluntary forest carbon offset projects in China.

\begin{tabular}{|c|c|c|}
\hline Stakeholder & Role orientation & Main driving factors \\
\hline CGCF & Organizer and investor & Forest carbon sequestration increase \\
\hline Firm & Donor & Carbon credits and good social image \\
\hline Individual & Donor & Carbon credits and good social image \\
\hline Forest-planting entity & Planter and forest manager & Revenue from forest planting and management \\
\hline Buyer of carbon credits & Buyer & Social responsibility or carbon offsets \\
\hline Farmer & Lumber owner and land supplier & $\begin{array}{c}\text { Lumbers ownership, labor income, and training } \\
\text { opportunities }\end{array}$ \\
\hline Government & Policy and subsidy supporter & Ecological and social benefits \\
\hline Community & - & Improvement in environment and infrastructure \\
\hline $\mathrm{NGO} / \mathrm{NPO}$ & Aids and information supporter & - \\
\hline $\begin{array}{l}\text { Advisory agency and certificate } \\
\text { authority }\end{array}$ & Designer of project design document & Fees \\
\hline
\end{tabular}

collective-owned forest land. The latter is mainly used and managed by farmers because its use right had transferred to farmers since forest tenure reform [37]. This transition determined that the use right of all involved collective-owned forest land would belong to farmers in the next 50-70 years. Currently, the vast majority of forest land involved in CGCF voluntary forest carbon offset projects is collective-owned. Therefore farmers become the principal suppliers of forest land for forest carbon offset projects. For instance, the Project Design Document showed that, out of all the 4,196.8 hectares of forest land, 2,857.5 hectares (about 68\%) was supplied by farmers in the CDM reforestation project in Pearl River Basin.

There exist two modes for farmers to participate in CGCF voluntary forest carbon offset projects. A few farmers would like to invest in afforestation/reforestation and take charge of daily forest management just as forest-planting entities do and finally turn into developers of CGCF voluntary forest carbon offset projects. These farmers will gain the benefits of forest carbon transaction besides selling lumber in the future. Others may directly entrust their land to CGCF for developing voluntary forest carbon offset projects, rather than directly undertaking the afforestation/reforestation as well as forest management themselves. These farmers only own the property right of lumbers on their forest land. Of course, they could be employed by forest-planting entities and then participated in afforestation/reforestation and forest management. Because of the small amount of own forest land, labor shortage, and lack of advanced technology for afforestation/reforestation and capacity for the effective forest management, the overwhelming majority of farmers participate in CGCF voluntary forest carbon offset projects with the later mode.

Actually not every farmer in project area is willing to participate in CGCF voluntary forest carbon offset projects. The farmer's participation willingness depends mainly upon the opportunity cost of land use and the chief industries the farmer's families engaged in. For example, the originally planned forest land area of one CGCF voluntary forest carbon offset project in Sichuan Province was 3,000 hectares; however only 2,300 hectares of forest land was finally involved. The low participation willingness of farmers is mainly due to the high opportunity cost of land use right transference. More economic benefits can be obtained if the land is used for planting tobacco, walnut, Camellia oleifera, and other commercial crops compared with forest carbon sequestration.

Forest-planting entities include the firms engaged in carbon sink forest plantation and management entrusted by CGCF. In CGCF voluntary forest carbon offset projects, forest-planting entities act as the operators of carbon credits generation. In particular, forest-planting entities are always one of the major donors of CGCF as well. Consequently, many voluntary forest carbon offset projects are driven by not only CGCF but also forest-planting entities. There may be totally four reasons for the forest-planting entities' participation in CGCF voluntary forest carbon offset projects. Firstly, the forest-planting entities can obtain benefit from CGCF by selling the service of forest plantation and management. Secondly, government subsidy for afforestation/reforestation is another major economic driver of forest-planting entities' participation. In most cases, the forest-planting entities are subsidized by government according to the standard of forestry ecological engineering (about 4,500 CNY per hectare). Thirdly, the high economic returns are always expected by donors when they also act as forest-planting entities. By directly participating in the forest plantation and management, donors can bring down the cost of generating carbon credits. Finally, most forest-planting entities believe that they can seize more opportunities in forest carbon credits transaction by accumulating more participation experience and management knowledge.

3.2. Power-Benefit Matrix Analysis of Stakeholders. According to the role orientation and driving factors of stakeholders involved in CGCF voluntary forest carbon offset projects in China, a Power-Benefit Matrix is established for stakeholders (Table 2).

3.2.1. Powers and Benefits of Stakeholders. Buyer of carbon credits may obtain relatively high economic and social benefit 
TABLE 2: Power-Benefit Matrix of stakeholders in CGCF voluntary forest carbon offset projects in China.

\begin{tabular}{ccc}
\hline & \multicolumn{2}{c}{ Benefit level } \\
\hline Power level & High \\
Low & NGO/NPO & \\
& Advisory agency and certificate & Buyer of carbon \\
authority & credits \\
High & Donor (firm and individual) & Forest-planting \\
& Community & entity \\
& Government & Farmer \\
\hline
\end{tabular}

by purchasing carbon credits. Currently, the forest carbon transaction occurred in a buyer's market. The market is very competitive for suppliers of carbon credits. The price of carbon credits is determined by buyers' willingness under the regulation of the government's GHG reduction policies. Therefore, the supplier should pay close attention to policy changes and be conscious of willingness changes of the possible buyers. However, the buyer of carbon credits can hardly influence the launch, implementation, and effectiveness of CGCF voluntary forest carbon offset projects which is mainly determined by nonprofit factors.

Donor (firm and individual), community, government, and CGCF own a relatively high level of power in CGCF voluntary forest carbon offset projects. As important providers of funds, the donors exert significant influence on the launch of projects but may not care too much about the benefit. The behaviors or decisions of community, government, and CGCF are crucial to the projects though they hardly obtain any economic benefit in this process.

Forest-planting entities and farmers not only have high level of power but also benefit a lot from CGCF voluntary forest carbon offset projects. The effectiveness of the projects is directly affected by forest-planting entities which are the operators of afforestation/reforestation and forest management. By participating in the projects and selling their services, forest-planting entities can get corresponding profit. Farmers are the original owners of land use right and their willingness determines the projects' scale. They can obtain relatively high benefit because of owning lumber produced in the projects.

3.2.2. Farmers' Acceptance for Benefit Allocation. Payment for forest-based carbon sequestration may be an emerging opportunity to mitigate climate change while creating new income streams for farmers. As main suppliers of land and labor, farmers have the right to share the benefit of CGCF voluntary forest carbon offset projects with the forestplanting entities. Their acceptances of the projects are largely determined by the method of benefit allocation. However, they do not take part in the planning, budgeting, and managing and lack information about total benefit of the projects. Consequently, the acceptance for benefit allocation from farmers depends on the opportunity cost of the land including fertility, original use, location, road conditions, and government policy. The benefit gained from the projects should offset the opportunity cost of the land at least. The transaction cost would be huge if negotiation was conducted with each farmer for each piece of land. Therefore, it is a common practice to make negotiations between the forestplanting entities and representatives from the farmers and communities. Once a consensus is reached, most of the farmers may accept the pay from forest-planting entities for their land and labor.

3.2.3. Motivator of Forest-Planting Entity. The cost of CGCF voluntary forest carbon offset projects, including production cost and transaction cost, is the major obstacle for private landowners in participating in carbon credit market. In Eastern China especially in the developed areas such as Guangdong, Beijing, Tianjin, Shanghai, Zhejiang, and Fujian, the cost of forest carbon sequestration is much higher (an average of 2,042.62 CNY per ton of carbon) compared with those in southwest, northwest, and northeast regions (averaged at 819.42 CNY per ton of carbon) [38]. Meanwhile the carbon credits generated by CGCF voluntary forest carbon offset projects were priced at $18 \mathrm{CNY}$ per ton, far below the carbon credits price of CDM AR projects ranging from 25 to $70 \mathrm{CNY}$ per ton. Nevertheless, CDM AR projects are mainly located in the southwest and northeast of the country, and the CGCF voluntary forest carbon offset projects are concentrated in Guangdong, Beijing, Zhejiang, Fujian, and so forth. This phenomenon indicates that cost and price are not the decisive factors of CGCF voluntary forest carbon offset projects. The key lies in policy guidance and incentive measures of government under the condition of incomplete market. The carbon credits are actually appendages to afforestation and reforestation. The forest-planting entity will participate in a CGCF voluntary forest carbon offset project as long as its net benefit exceeds that of traditional forestry or the benefit from carbon credits is more than the extra cost incurred in carbon credits production and transaction.

3.2.4. Roles of CGCF, Government, and Community. CGCF, government, and community are more likely to win trust from other stakeholders due to their information superiority and having no apparent interest conflict with others. Meanwhile, their active participations are crucial to the successful implementation of CGCF voluntary forest carbon offset projects.

An effective governance mode is able to coordinate the stakeholders' interests through formal or informal institutions so as to avoid conflicts. The existence of CGCF is one of the major differences between voluntary forest carbon offset projects and CDM AR projects. Due to the absence of mature carbon credit market, CGCF actually plays the roles of leadership, demonstration, and medium, providing a communication platform for the buyers and sellers, which effectively reduces the information search cost and improves trading efficiency.

Policy clarity and perfection and regulation of institution are the keys to forest carbon market development $[39,40]$. Experience shows that the implementation of prevenient 
CGCF voluntary forest carbon offset projects is virtually impossible without effective participation and support of the government. The government departments and agencies involved in the projects mainly refer to the competent forestry departments and the municipal and township governments, which affect the implementation of CGCF voluntary forest carbon offset projects through three ways. Firstly, government helps to discover partners for the projects and directly or indirectly facilitates the forest carbon transactions between buyers and sellers. Secondly, government coordinates the beneficial relationships between the partners and ensures the smooth implementation of the projects and transactions. Thirdly, fund from government plays a guiding and substantive role that cannot be substituted. Take Wenzhou Carbon Credit Fund as an example, of all the raised funds of 74.3 million CNY, $40 \%$ (or 30.3 million CNY) come from the municipal government. Furthermore, most CGCF voluntary forest carbon offset projects could get afforestation subsidy from government. This is one of the main reasons that forestplanting entities are willing to take part in the projects and share more benefit out to farmers.

As a vital stakeholder of CGCF voluntary forest carbon offset projects, the community as well as its interests must be considered. Unlike forestry-planting entities and farmers who mainly focus on economic returns, community is more concerned with environmental and social benefit such as improvement in infrastructure, education and training, ecological environment, and access to the forest. Although these willingness can conflict with goals of economic benefit maximization of forestry-planting entities and farmers more or less, they have to be taken into account as much as possible. A real-world example is that the original plan had been altered in Wenzhou Carbon Credit Project because the community opposed planting too many fast-growing eucalypt trees.

\section{Conclusions}

The voluntary forest carbon offset projects are highly valued to boost forest carbon storage and mitigate global warming and will become the major form of forest carbon transaction in China. The empirical analysis of stakeholders indicates that a win-win solution is possible in CGCF voluntary forest carbon offset projects in China through stakeholders' joint participation and compromise, although the interests of government, forest-planting entities, farmers and community, and so forth are different. A wide governance structure laying emphasis on benefit balance, equality, and information exchanges and being regulated by all stakeholders has been constructed. It facilitates the agreement among the stakeholders with conflicting or different interests. Due to this governance structure, the functions such as carbon sequestration, environment conservation, and ecological restoration of forest are brought into play through financial subsidies, preferential taxations, and some other encouraging measures. In particular, the fund from government for voluntary forest carbon offset projects not only helps to increase the direct economic benefits of the forest-planting entities and farmers but also plays a substantive role in guiding donation. In sum, the joint participation of stakeholders in voluntary forest carbon offset projects might change the governmentdominated afforestation/reforestation into a market, where all participators including government are encouraged to cooperate with each other to improve the condition of fund shortage and low efficiency. The analysis of stakeholders in this study is based on the hypothesis of ration while decisions of stakeholders are always influenced by psychology or belief. This is especially true for famers because they lack information. The irrationalities of stakeholders should be discussed in future studies.

\section{Conflict of Interests}

The authors declare that there is no conflict of interests regarding the publication of this paper.

\section{Acknowledgments}

This research was supported by China National Natural Science Funds for Distinguished Young Scholar (no. 71225005), the National Scientific Foundation of China (no. 41171434), and the Foundation for High-level Talents of Qingdao Agricultural University (no. 2017).

\section{References}

[1] B. Metz, O. R. Davidson, P. R. Bosch, R. Dave, and L. A. Meyer, Climate Change 2007: Mitigation, Cambridge University Press, Cambridge, UK, 2007.

[2] World Meteorological Organization, World Meteorological Organization Statement on the Status of the Global Climate in 2003, World Meteorological Organization, Geneva, Switzerland, 2003.

[3] D. J. Frame and D. A. Stone, "Assessment of the first consensus prediction on climate change," Nature Climate Change, vol. 3, no. 4, pp. 357-359, 2013.

[4] B. Schlamadinger, N. Bird, T. Johns et al., "A synopsis of land use, land-use change and forestry (LULUCF) under the Kyoto Protocol and Marrakech Accords," Environmental Science and Policy, vol. 10, no. 4, pp. 271-282, 2007.

[5] R. J. Zomer, A. Trabucio, D. A. Bossio, and L. V. Verchot, "Climate change mitigation: a spatial analysis of global land suitability for clean development mechanism afforestation and reforestation," Agriculture, Ecosystems \& Environment, vol. 126, no. 1-2, pp. 67-80, 2008.

[6] J. Zhan, H. Yan, B. Chen, J. Luo, and N. Shi, "Decomposition analysis of the mechanism behind the spatial and temporal patterns of changes in carbon bio-sequestration in China," Energies, vol. 5, no. 2, pp. 386-398, 2012.

[7] W. M. Budzianowski and D. C. Budzianowska, "Allocation of ecologically allowable carbon emissions to countries as a key to more effective post-Kyoto Protocol climate change mitigation law," International Journal of Global Warming, vol. 4, no. 2, pp. 113-133, 2012.

[8] X. Deng, Q. Jiang, J. Zhan, S. He, and Y. Lin, "Simulation on the dynamics of forest area changes in Northeast China," Journal of Geographical Sciences, vol. 20, no. 4, pp. 495-509, 2010. 
[9] J. Shi and L. Cui, "Soil carbon change and its affecting factors following afforestation in China," Landscape and Urban Planning, vol. 98, no. 2, pp. 75-85, 2010.

[10] S. Brinkel and R. Antes, "Voluntary carbon offsets-empirical findings of an international survey," in Emissions Trading, R. Antes, B. Hansjurgens, P. Letmathe, and S. Pickl, Eds., pp. 243262, Springer, Berlin, Germany, 2011.

[11] L. Peskett, K. Schreckenberg, and J. Brown, "Institutional approaches for carbon financing in the forest sector: learning lessons for REDD+ from forest carbon projects in Uganda," Environmental Science and Policy, vol. 14, no. 2, pp. 216-229, 2011.

[12] C. S. Galik, D. M. Cooley, and J. S. Baker, "Analysis of the production and transaction costs of forest carbon offset projects in the USA," Journal of Environmental Management, vol. 112, pp. 128-136, 2012.

[13] S. Wu, "Forestry market perspective and transaction strategies for forestry CERs under CDM," Scientia Silvae Sinicae, vol. 46, no. 11, pp. 152-157, 2010 (Chinese).

[14] X. Cao, M. Seol, and Y. Yeo-Chang, "An exploratory study on forest carbon markets in Asia," Forest Science and Technology, vol. 8, no. 1, pp. 34-37, 2012.

[15] M. Markowski-Lindsay, T. Stevens, D. B. Kittredge, B. J. Butler, P. Catanzaro, and B. J. Dickinson, "Barriers to Massachusetts forest landowner participation in carbon markets," Ecological Economics, vol. 71, no. 1, pp. 180-190, 2011.

[16] K. A. Miller, S. A. Snyder, and M. A. Kilgore, "An assessment of forest landowner interest in selling forest carbon credits in the Lake States, USA," Forest Policy and Economics, vol. 25, pp. 113-122, 2012.

[17] R. Birdsey, K. Pregitzer, and A. Lucier, "Forest carbon management in the United States: 1600-2100," Journal of Environmental Quality, vol. 35, no. 4, pp. 1461-1469, 2006.

[18] J. C. Milder, S. J. Scherr, and C. Bracer, "Trends and future potential of payment for ecosystem services to alleviate rural poverty in developing countries," Ecology and Society, vol. 15, no. 2, p. 4, 2010.

[19] D. Wade and C. Moseley, "Foresters' perceptions of family forest owner willingness to participate in forest carbon markets," Northern Journal of Applied Forestry, vol. 28, no. 4, pp. 199-203, 2011.

[20] D. W. Thompson and E. N. Hansen, "Carbon storage on nonindustrial private forestland: an application of the theory of planned behavior," Small-Scale Forestry, vol. 12, no. 4, pp. 631657, 2013.

[21] S. L. Cook and Z. Ma, "Carbon sequestration and private rangelands: Insights from Utah landowners and implications for policy development," Land Use Policy, vol. 36, pp. 522-532, 2014.

[22] I. J. Visseren-Hamakers, B. Arts, and P. Glasbergen, "Interaction management by partnerships: the case of biodiversity and climate change," Global Environmental Politics, vol. 11, no. 4, pp. 89-107, 2011.

[23] P. Lamers and M. Junginger, "The "debt" is in the detail: a synthesis of recent temporal forest carbon analyses on woody biomass forenergy," Biofuels, Bioproducts and Biorefining, vol. 7, no. 4, pp. 373-385, 2013

[24] Y. Ding, G. Ren, G. Shi et al., "National assessment report of climate change (I): climate change in China and its future trend," Advances in Climate Change Research, vol. 2, no. 1, pp. 3-8, 2006.

[25] NDRC, China's Policies and Actions for Addressing Climate Change-The Progress Report 2009, NDRC, Beijing, China, 2009.
[26] S. Thomas, P. Dargusch, S. Harrison, and J. Herbohn, "Why are there so few afforestation and reforestation Clean Development Mechanism projects?" Land Use Policy, vol. 27, no. 3, pp. 880887, 2010.

[27] E. Liu and S. Liu, "Climate change mitigation through forestbased carbon sequestration projects in China: potential benefits and challenges," Advanced Materials Research, vol. 255-260, pp. 2949-2952, 2011.

[28] Y. Huang, "Policy experimentation and the emergence of domestic voluntary carbon trading in China," East Asia, vol. 30, no. 1, pp. 1-23, 2013.

[29] S. Wu, X. Zhang, and W. Song, "Carbon offset standard for international voluntary carbon sequestration market," Scientia Silvae Sinicae, vol. 45, no. 3, pp. 134-139, 2009.

[30] R. J. Zomer, A. Trabucco, L. V. Verchot, and B. Muys, "Land area eligible for afforestation and reforestation within the clean development mechanism: a global analysis of the impact of forest definition," Mitigation and Adaptation Strategies for Global Change, vol. 13, no. 3, pp. 219-239, 2008.

[31] X. Zhu, Y. Hou, and Y. Li, "A case study of forest carbon trade in China: Sino-forest funded protection of natural secondary forests in Heyuan City, Guangdong," Forestry Science and Technology, vol. 8, no. 2, pp. 38-45, 2009.

[32] Y. Ying and J. Li, "SWOT analysis of forest carbon-sink market transaction in China," in Proceedings of the National Conference on Information Technology and Computer Science (CITCS '12), pp. 1065-1068, Lanzhou, China, November 2012.

[33] J. Sarkis, Q. Zhu, and K.-H. Lai, "An organizational theoretic review of green supply chain management literature," International Journal of Production Economics, vol. 130, no. 1, pp. 1-15, 2011.

[34] K. de Brucker, C. MacHaris, and A. Verbeke, "Multi-criteria analysis and the resolution of sustainable development dilemmas: a stakeholder management approach," European Journal of Operational Research, vol. 224, no. 1, pp. 122-131, 2013.

[35] M. C. Jensen, "Value maximization, stakeholder theory, and the corporate objective function," Journal of Applied Corporate Finance, vol. 22, no. 1, pp. 32-42, 2010.

[36] C. Connelley and P. Tripodi, Aspects of Leadership: Ethics, Law, and Spirituality, Marine Corps University Press, Quantico, Va, USA, 2012.

[37] Z. Zhu, Y. Shen, W. Wu, X. Xu, and C. Zeng, "Household optimal forest management decision and carbon supply: case from Zhejiang and Jiangxi provinces," Acta Ecologica Sinica, vol. 33, no. 8, pp. 2577-2585, 2013.

[38] W. Zhong and Z. Xing, "Analysis on cost and benefit of carbon sequestration in each province of China: based on afforestation and reforestation project," China Population Resources and Environment, vol. 22, no. 9, pp. 33-41, 2012 (Chinese).

[39] P. Dargusch, S. Harrison, and S. Thomas, "Opportunities for small-scale forestry in carbon markets," Small-Scale Forestry, vol. 9, no. 4, pp. 397-408, 2010.

[40] Z. Ying, M. Gao, J. Liu, Y. Wen, and W. Song, "Green accounting for forest and green policies in China-a pilot national assessment," Forest Policy and Economics, vol. 13, no. 7, pp. 513-519, 2011. 

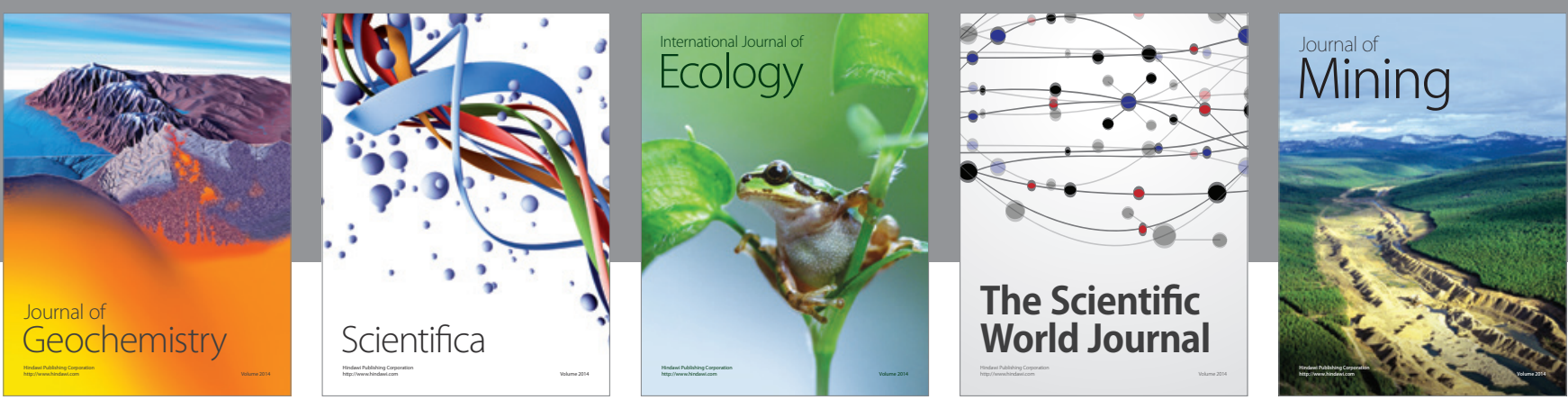

The Scientific World Journal
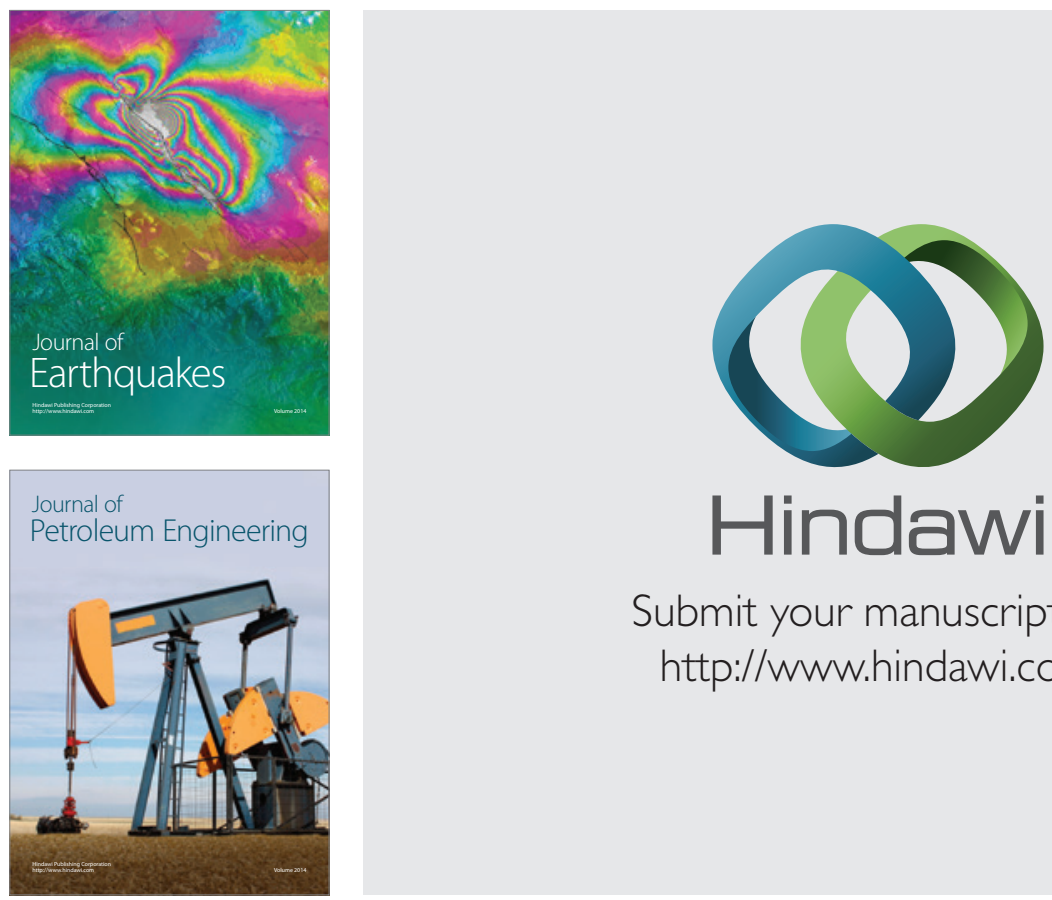

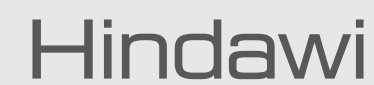

Submit your manuscripts at

http://www.hindawi.com
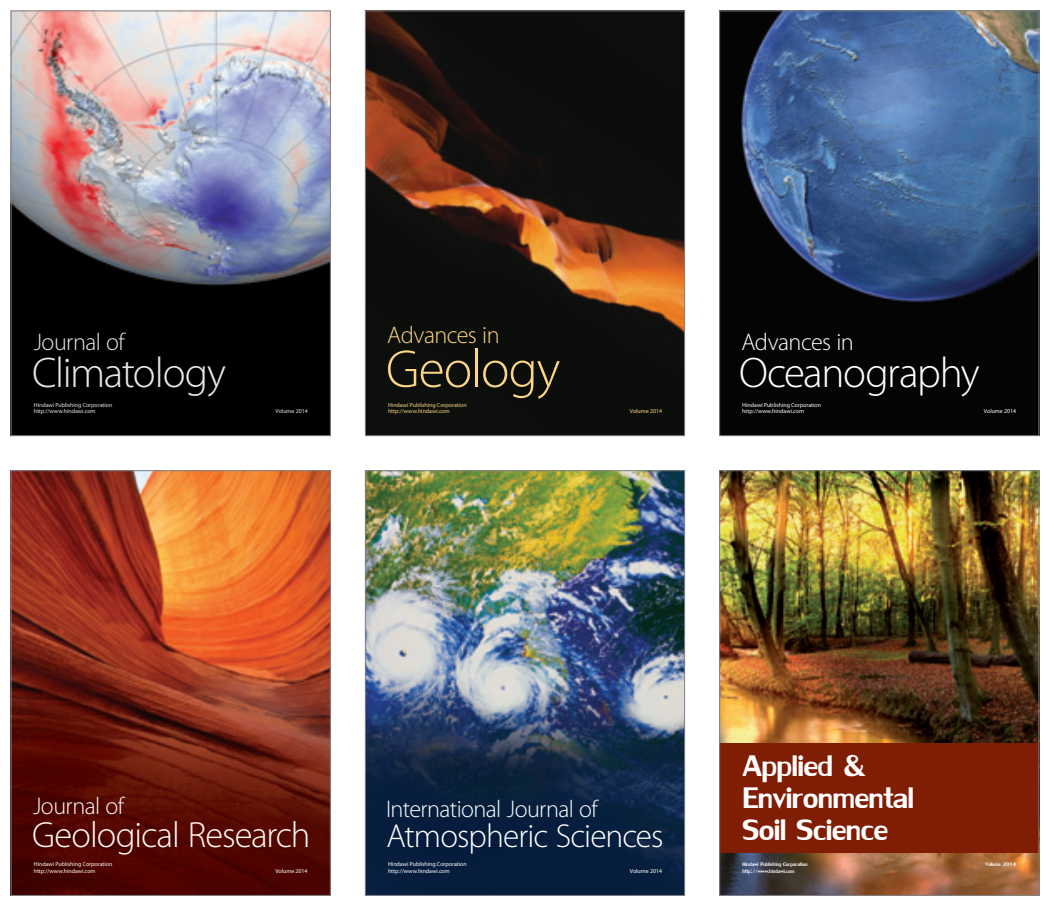
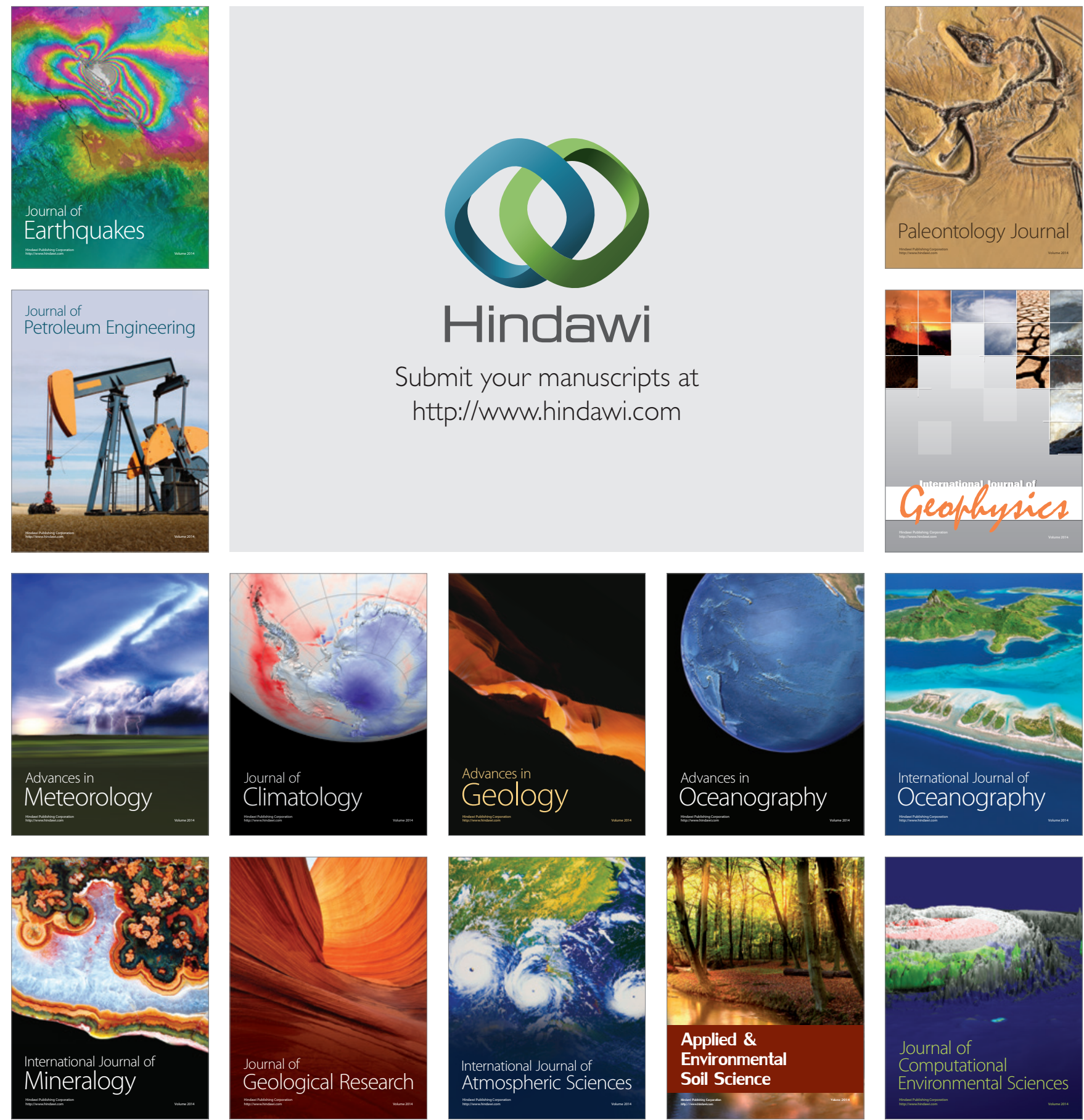